\title{
Maple Leaf Foods: Crisis and containment case study
}

\author{
GWYNETH V.J. HOWELL ${ }^{*}$ \\ University of Western Sydney \\ ROHAN MILLER $^{* *}$ \\ University of Sydney
}

\begin{abstract}
Crises can impact an organisation's viability, credibility and reputation. Communication can preserve and protect the valuable reputation of an organisation, by demonstrating an acceptance of responsibility for the crisis and addressing victim concerns. The research illustrates that Maple Leaf Food's crisis communication strategy was effectual and in supported to its purported organisational values as an organisation focused on health and safety. This case highlights why it is crucial for organisations to develop and apply a cohesive crisis communication strategy.
\end{abstract}

\section{Introduction}

A crisis is a fluid, unstable, dynamic situation, (Fink, 1986) that brings an organisation into disrepute and threatens its future profitability, growth, and survival (Lerbinger, 1997). A crisis can have many and varied impacts on an organisation, from a drastic fall in the company's share price to customers looking toward competitors for a better or safer product (Millar \& Heath, 2004). In a crisis situation the greatest danger is the erosion of a company's reputation (Lerbinger, 1997; Coombs, 2007). There are a range of consumable product crises that have affected the reputation of the organisation. These include the1994 Schwan's ice cream salmonella outbreak and the 2005 Wendy's “finger-in-the-chilli" incident in the U.S.A., the 2005 Masterfood's Mars and Snickers bars product recall in Australia, and the 2007 salmonella scare in the U.K. that forced Cadbury Schweppes to recall more than one million of its chocolate bars at a cost of $£ 20 \mathrm{~m}$ and a loss 7 percent in market share.

Two major product recalls occurred in 2008. The first concerned the global recall of Chinese milk products when it was found that 10 percent of the milk from the country's two largest dairy manufacturers (Mengniu Dairy Group and Yili Industrial Group) contained up to 8.4 milligrams of melamine per kilogram. The second involved one of Canada's most respected food processing companies, Maple Leaf Foods. The firm's reputation rapidly dissipated when it was announced that a bacteria had not been detected by its inspection process (Flynn, 2009). It was further confirmed "packaged meat from Maple Leaf's Toronto plant was killing people” (Pitts, 2008, p. 46). This event cost the company \$30million during the recall with 21 deaths being attributed to $L$. monocytogenes, the deadly bacteria found in one of Maple Leaf's processing plants (Public Health Agency of Canada, 2008). Within the Maple Lead Food range, 234 products were recalled, damaging the organisation's reputation as well as market share as other competing products quickly filled the void. 
Kumar and Budin (2006) suggest that the media has an increasing appetite for food safety disasters. Doeg (2005) claims "in the case of a food scare or a crisis ... the media are frequently blamed for exaggerating the matter, taking it out of context, or even distorting the facts” (p. 58). Therefore, it is imperative that an organisation develop sound relationships with media, and that media is used as a positive communication tool to reduce consumer anxiety and the organisation's potential reputational damage from negative media scrutiny during the crisis. Crisis communications practices have expanded to use both traditional and new media outlets to communicate their key messages to key publics (Arpan \& Pompper, 2003; Fearn-Banks, 2007). It is commonly suggested that new media have drastically altered the way organisations communicate during a crisis (Kimmel, 2004; Jaques, 2008) and that the digital revolution has caused crisis communication to evolve. Key publics now require instantaneous, exhaustive, global information required about the crisis by key publics (Barr, 2000). How the organisation manages a contamination crisis determines how successful the organisation is at regaining market share for the targeted product. Ensuring that the key messages developed are successfully communicated to the key publics is therefore crucial to ensure success.

Crisis communications is the dialogue between the organisation and its publics prior to, during, and after the negative event (Fearn-Banks, 2007). It is emphasized that "communicating does not simply mean being able to send messages, it also means being able to receive them" (Lagadec, 1993 p. 14). It is important that crisis communications are quickly actionable as typically "the public will quickly begin to look for a trusted and consistent source of information” (Russell, cited in Galloway and Kwansah-Aidoo, 2005, p. 95). Best practice crisis communications is designed to maintain public confidence and minimising damage suffered (Levine, 2002). As organisations use mass media to communicate their key messages to stakeholders during crises (Arpan and Pompper, 2003; Fearn-Banks, 2007), the way mass media frame coverage and the manner in which those key messages are interpreted by the key publics can adversely affect the organisation (Pan \& Kosicki, 1993; Patterson, 2004). A recent study conducted by Oxford University identified more than 90 percent of communication during a crisis was not controlled by the company in focus; it was the media that set the agenda in terms of coverage (Kirk cited in Cincotta, 2005, para. 9). This illustrates that media liaison is critical during times of crisis. As noted, the media's influence over crises has evolved and increased with the digital revolution (Barr, 2000; Kimmel, 2004; Michelson \& Mouly, 2002).

\section{Method}

This paper uses a case-based methodology to undertake a comprehensive and systematic description of the organisation and the issues it faced, and critically examines the communication strategies and tactics employed by Maple Leaf Foods during the 2008 contamination crisis. Publically available literature was reviewed, including documents released by Maple Leaf Foods, information found on their corporate website and articles written about the crisis from various news outlets. In examining Maple Leaf Foods' response to the L. monocytogenes outbreak, best practices in crisis communication management are evident, illustrating that opportunities exist in a crisis that can help organisations become stronger and more resilient - especially in today's demanding and evolving environment (Ulmer, Seeger \& Sellnow, 2007). In the case examined, the company framing of a matter of significant public interest (i.e., contaminated small goods) ultimately enhanced the organisation's reputation and also strengthened customer loyalty to the contaminated product. 


\section{Maple Leaf Foods}

Maple Leaf Foods Inc. is a prominent food processing company headquartered in Toronto, Canada. The company employs approximately 24,000 people across Canada, the U.S.A., Europe and Asia. In 2008 the Toronto-based firm recorded sales of \$5.2 billion. Maple Leaf Foods prides itself on its commitment to food safety, stating that its meat processing facilities are federally inspected and meet the highest standard for food safety in Canada. Further, the organisation publicly claims that it is compliant with a scientific preventative food safety system, Hazard Analysis Critical Control Points (HACCP), which is recognized as the gold standard worldwide (Maple Leaf Foods, 2009a).

During the Northern Hemisphere summer of 2008, the Canadian Food Inspection Agency and Public Health Agency of Canada identified a strain of L. monocytogenes (listeria) in Maple Leaf Foods products. This led to a recall of 243 types of ready-to-eat meat products. Despite Maple Leaf Foods' commitment to, its stringent food safety procedures failed to identify a strain of L. monocytogenes bacteria that led to the death of 21 Canadians (Maple Leaf Foods, 2009b). Consumption of food contaminated with L. monocytogenes may cause Listeriosis, a rare illness caused by eating food contaminated with bacteria called Listeria. Symptoms include fever, muscle aches and sometimes gastrointestinal symptoms such as nausea and diarrhoea. In the more severe form, symptoms also include collapse and shock. (New South Wales Food Authority, 2006). Infection during pregnancy can lead to premature delivery (abortion), infection of the newborn, and still birth (New South Wales Food Authority, 2006).

Bacteria were traced to the slicing equipment at Maple Leaf's Bartor Road plant in Toronto. Regular sanitisation had not cleaned the equipment properly allowing $L$. monocytogenes to grow to high levels of concentration that cause illness. The bacteria ended up in deli meats, which were largely distributed to nursing homes and hospitals.

\section{Crisis communication strategy}

Crises are events that often occur suddenly and without warning (e.g., Barton, 1993; Dawar, 1998; Fearn-Banks, 2007; Mitroff, 1994; Seymour \& Moore, 2000; Coombs, 2007) and disrupt the normal operations of an organisation. As such, it is important to identify best practice in the management of these events. The media's ability to communicate news as soon as it happens has forced organisations to develop crisis strategies that can be implemented expeditiously (Fink, 1986). It is vital for an organisation to communicate throughout the crisis with its stakeholders using the most effective communication channels available (Fearn-Banks, 2007; Coombs, 2007). Traditionally, the crisis communication literature focused on practical recommendations for predicting and preparing for crises, developing crisis management plans (e.g., Barton, 1993; Mitroff, 1994), and for effective communication during a crisis. However, this approach is increasingly being challenged by those arguing that a prescriptive approach in crisis communication must incorporate the need to build and manage relationships with key stakeholders (Ledingham, 2006). Jaques (2008) suggests that various crisis theories support the idea that organisations with crisis communication programs are better prepared to manage crises, and therefore suffer less damage from the experience. Fearn-Banks (2007) suggests that from the outset of the crisis, organisations have the opportunity to influence events. Significantly, Maple Leaf Foods was able to manage an agenda in terms of media content of the crisis. Further, in an analysis of the media coverage and information released by Maple Leaf Foods the four key communication themes emerged: product safety, Government investigation, corporate reputation and product reputation. 
Diligence is an essential aspect of effective crisis communication. Communications strategies will only be successful if all avenues are explored and public relations practitioners are prepared for the unexpected (Fearn-Banks, 2007). Effective crisis communication management is based on how rapidly an organisation can respond to a crisis. This then requires an organisation to act in a proactive manner to best manage potentially dangerous situations and issues (Cincotta, 2005; Hendrix, 2001; Stacks, 2005). The proactive response to the recall by Maple Leaf Foods enforced the precedence that the company placed public interest and safety above the financial costs of the crisis (Ewing, 2009). Johnson and Zawawi (2002) suggest that a lack of anticipation and preparation can increase the difficulty for public relations practitioners to negate negative perceptions. Further, Coombs (1999) asserts that "not all crises can be prevented, so organizational members must prepare" (p. 219). While academics and practitioners suggest that best practice for crisis management is proactive rather the reactive, the nature of this crisis limited the level proactive management an organisation could undertake. Matera and Artigue (2000) recommend "if management regards public relations functions as important, then the chances are good that a corporation can successfully emerge from disaster" (p. 216).

To explore the communication tactics employed during the crisis, Seymour and Moore's (2000) 5Cs of communication framework has been employed. Seymour and Moore's (2000) model suggests that internal and external communication in a crisis should meet five key criteria, these being:

Care: communication should indicate that the company cares about the problem and empathizes with those affected. Commitment: the company must declare and act to demonstrate their will to solve the problem, find the cause, and prevent it from happening again. Consistency and Coherence: all communication and all spokespeople should say the same thing. Clarity: crisis problems should be clearly explained and should clarify the company’s position and actions (Seymour \& Moore, 2000, p. 99).

The analysis demonstrates that the company's crisis communication strategy was largely effectual in dealing national product recall.

\section{Care}

From August 2008 to March 2009, there were 21 confirmed deaths resulting from the Listeria outbreak (Maple Leaf Food, 2009b). President and Chief Executive Officer of Maple Leaf Foods, Michael McCain, stated that "this was by far the most awful event in the one hundred year history of our company" (Maple Leaf Foods, 2009b, para. 6). During the peak of the crisis, "Maple Leaf's brand sales had dropped more than 30 per cent” (Lam, 2009, para. 9). According to Fearn-Banks' (2007) crisis life cycle model, this represents the "Acute Stage," of the crisis - when it is at the most intense stage. However, despite the loss Maple Leaf experienced at this point, the company survived, and in January 2009, 70 to 75 per cent of those sales were recovered (Harris, 2009, para. 17). Maple Leaf Foods managed the uncertainty of the recall and demonstrated care by making the company's senior management visible and available to the media and the public for the full duration of the crisis.

Maple Leaf Foods employed a range of communication tactics. At the initial media conference, Michael McCain announced that the company would begin its recall of a range of Maple Leaf Foods products. The contrite video set the tone for the crisis communication response. Matheson (2008) suggests "what is rare, and decidedly refreshing, is the unconditional apology and unequivocal responsibility Maple Leaf Foods has offered and assumed through company president Michael McCain” (Matheson, 2008, p. C8). This 
response is now being touted as best practice for the organisation's transparency and focus on consumers' health over that of the bottom line (Harris, 2009).

Over the course of the crisis, McCain undertook a series of press conferences and became the public face of Maple Leaf Foods. The organisation's apology was publicly available from its website as well as footage of each media conference. Maple Leaf Foods released backgrounders, fact sheets and FAQ documents to further inform the public demonstrating care for its key stakeholders. Experts praised Maple Leaf Foods for using McCain to communicate with the public. "I think for the chief executive to be on camera about it is the most effective way, and probably the only thing that should be done in a situation like this" (Watt cited in CBC News, 2008). This response in demonstrating care is also a lesson to other organisations. "I think time will show that they have significantly redefined the way corporate entities will respond in crisis situations in the future," explained Bob Reid, chief media strategist at Toronto-based Veritas Communications. "It was an honest, compassionate response that defied the usual tap dance that naturally comes into play any time there is potentially legal liability" (Harris, 2009, para. 7).

\section{Commitment}

Maple Leaf Foods successfully presented itself to its publics as a company that was willing to do what was right - regardless of the cost. As a result, it regained its status as a market leader in the production and sale of small goods within twelve months (Harris, 2009). The company advertised detailed lists of recalled products and endeavoured to communicate information about the bacteria, post-contact information both online and through traditional media sources, and encouraged consumers, shareholders and stakeholders to visit their website frequently for more information (Abbymartin, 2008). By shutting down its Bartor Road plant Toronto, initiating a nationwide recall, and taking all precautionary measures necessary to minimize risks, Maple Leaf Foods regained consumer confidence by late 2008.

Maple Leaf Foods assembled a consortium of industry leading food safety experts, including officials from the Canadian Food Inspection Agency and the Public Health Agency of Canada (PHAC) to advise the company on the various physical and operational enhancements they were looking to implement (Smith, 2008). Following the consortium's recommendations, Maple Leaf Foods undertook a number of plant-wide measures to ensure the public would have complete confidence in their products. Among a range of provisions, the affected plant underwent six intensive sanitisations (a figure that was well in excess normal cleaning procedures), under the supervision of microbiologists and sanitation experts (Smith, 2008). All slicing equipment was subjected to a daily disassembly, deep cleaning and multiple testing to verify the elimination of potential harborage points (Smith, 2008). Finally, a comprehensive pre-operation inspection conducted by the Canadian Food Inspection Agency was completed before any new products were distributed from the plant (Smith, 2008). Furthermore, upon the successful reopening McCain took groups of reporters on organised tours of the rejuvenated facility and the detailed the company's improved safety protocols (Godbout, 2008). While unique, such gestures epitomise Maple Leaf Foods' attempt to undertake an 'above and beyond' strategy to recover from the crisis and regain market confidence and market share.

\section{Consistency and coherence}

Maple Leaf Foods' response to the crisis was immediate and its key messages were always consistent. McCain took responsibility for the crisis, apologising repeatedly and expressing sympathy for those affected. The company demonstrated that it cared about the issue and empathised with the public. They expressed commitment by acting immediately and working diligently to identify the cause of the crisis, and eventual solution. All of Maple Leaf's 
messages were consistent, with a primary focus on assuring food safety and the well-being of its consumers. McCain proved an ideal spokesperson who clearly explained the company's position as well as the actions Maple Leaf was enacting to remedy the situation (Adams, 2008; Daniels, 2008).

Employing social media tactics, Maple Leaf Foods launched an external company blog to, "maintain a direct and candid conversation with interested Canadians" (Maple Leaf Foods, 2009b). In his first blog, McCain explained why the company was using new media:

We believe it is our responsibility to maintain honest and open communications on a subject that is of high interest and importance to everyone. This blog will engage leaders from Maple Leaf Foods including myself and Chief Food Safety Officer, Dr. Randall Huffman in a dialogue with citizens, consumers and others as we continue on our journey to food safety leadership (McCain, 2009, para. 8).

The blog also provided updates on the company's progress towards food safety leadership, addressed topics and questions related to listeria management and responded to new events and issues as they occurred (Maple Leaf Foods, 2009b).

\section{Clarity}

Maple Leaf Foods compensated victims and reached a settlement agreement with the principal counsel groups that launched a class action following the Listeriosis outbreak (Owram, 2009). This compensation effort sought to move beyond crisis and assist in renewal of the organisation's reputation. When Maple Leaf Foods announced, with support from appropriate authorities, that its products would be returning to retail outlets and were safe and ready for purchase, a media campaign was also developed to enhance the organisation's reputation. The rollout of the "Passionate people, passionate about food" campaign showed microbiologists working at the Toronto plant and then serving food to children in their homes (Harris, 2009). Maple Leaf Foods also launched www.mapleleafaction.com, a website dedicated to informing the public about steps being taken to improve food safety. This media and advertising campaign supported the public relations efforts Maple Leaf Foods had undertaken to restore its reputation by developing a trust-building campaign. This included a general media television campaign released in January 2009 with the tagline "Passionate people, passionate about food.”

Maple Leaf Foods positioned themselves as the experts on Listeria. The company recently launched a national Listeria education and outreach program exploring the issues related to this illness. It has been suggested that this tactic has enhanced the organisation's reputation as an industry expert regarding this issue. McCain also promised to continue being honest and transparent in all communications and invited feedback from the public. A blog was launched on 25 March 2009 to enhance dialogue with the community. The blog featured commentary about the company's progress, addressed Listeria related issues, posted videos and podcasts and allowed leaders from Maple Leaf Foods to engage in dialogue with individuals interested in food safety (Maple Leaf Foods, 2009c).

\section{Discussion}

Academics and practitioners suggest that best practice for crisis management is proactive rather than reactive communication (Jaques, 2007, Pearson, Misra, Clair, \& Mitroff, 1997; Penrose, 2000). The nature of a contamination crisis limits the extent of proactive management an organisation can undertake. As illustrated in this case, the care and safety of the organisation's customers must be the most important consideration when facing a 
contamination recall. How this is communicated to key publics is no less vital. Matera and Artigue (2000) suggest that "if management regards public relations functions as important, then the chances are good that a corporation can successfully emerge from disaster" (p. 216). While Maple Leaf Foods was not completely prepared for the event, its corporate culture assisted in the successful management of the crisis. The crisis cannot be considered a complete surprise (due to the history of recalls and knowledge of the issues faced by the manufactured food industry). However, the response to the 2008 crisis by McCain and his team of "very capable, committed, passionate people" was effective because of the ethos of the organisation and team's accountability for their individual and group actions in light of adversity (McCain cited in Ewing, 2009, para. 11). Revealingly, McCain has refused to claim the management of the crisis a success or failure:

We would be thankful if we can fully recover our business and we're optimistic we can earn that trust back from consumers, but these types of things rarely should be described in terms of success or similar adjectives, because this is just an outright tragedy (McCain cited in Ewing, 2009, para. 13).

Communication effectiveness is judged on its ability to satisfy the needs of the public (Heath, 2001). Although Maple Leaf Foods stakeholders are wide ranging, the crisis communication strategy ensured that all stakeholders were provided with extensive information, and cognition of the information provided was high. Averting a crisis is the greatest success for any public relations professional (Howell \& Miller, 2006). The management of the Listeria crisis by Maple Leaf Foods is now being described as "the gold standard" in effective crisis management (Tattrie, 2009, para. 10). It has been suggested that Maple Leaf's response to the listeriosis outbreak "a case study in how to effectively handle a crisis" (Todd, 2008, para. 1). However, the ongoing customer loyalty to the products cannot yet be determined with the information publicly available. While various national and international commentators have recognised Maple Leaf Food's communication success, customer loyalty and sales for 2009 will ultimately determine whether the ongoing viability of the brand has been strengthened.

Campbell (1999) views the crisis process as one of continual improvement. This also true for public relations research and practice. Averting a crisis is the greatest success for any public relations professional (Howell \& Miller, 2006). Maple Leaf Foods' crisis communication strategy ensured that all stakeholders were provided with extensive information, and cognition of the information provided was high. McCain's leadership and his open and honest approach and focus on public safety were the key to Maple Leaf Foods' success in managing the crisis. The response to the Listeria outbreak illustrates good practice in crisis communication management and is an interesting example of what organisations need to do survive when faced with a product recall crisis in the 21st century.

\section{References}

Adams, C. (2008, September 19). The Maple Leaf Foods crisis: One month later. Retrieved March 6, 2009, from http://www.princanada.com/the-maple-leaf-foods-crisis-one-month-later

Ahmed, M. (2006). Principles and practice of crisis management. New York: Palgrave Macmillan.

Abbymartin. (2008, August 26). Maple Leaf Foods and crisis management. Retrieved March 7, 2009, from http://abbymartin.wordpress.com/2008/08/26/maple-leaf-foods-and-crisis-management/

Arpan, L., \& Pompper, D. (2003). Stormyweather: Testing 'stealing thunder' as a crisis communication strategy to improve communication flow between organisations and journalists. Public Relations Review, 29(3), 291-308.

Baker, G. F. (2001). Race and reputation: Restoring image beyond the crisis. In R.L. Heath (Ed.), Handbook of public relations, (pp. 513-520). Thousand Oaks: Sage Publications. 
Barr, T. (2000). newmedia.com.au. Sydney: Allen \& Unwin.

CBC News. (2008, August 28). How Maple Leaf Foods is handling the Listeria outbreak. Retrieved March 6, 2009, from http://www.cbc.ca/money/story/2008/08/27/f-crisisresponse.html

Charlebois, S. \& Levene, K. (2009, January 13). Good leadership in trying times: PR strategy: Maple Leaf CEO steers his firm through crisis. National Post, p. 7.

Cincotta, K. (2005, October 31). Less fluff more facts, industry learns. B\&T: News. Retrieved May 8, 2006, from http://www.bandt.com.au/news/bd/0c037bbd.asp. Week US. Retrieved March 7, 2009, from http://www.prweekus.com/

Coombs, W. (2007). Ongoing crisis communication: Planning, managing and responding. New York: Sage Inc.

Department of Human Services. (2009). Listeria the Facts. Fact Sheet. Retrieved May 30, 2009, from http://www.health.vic.gov.au/_data/assets/pdf_file/0004/357637/listeria_pamph.pdf

Doeg, C. (1995). Crisis management in the food and drinks industry: A practical approach. London: Chapman \& Hall.

Duhe, S. C. (2007). New media and public relations. New York: Peter Lang Publishing.

Ewing, B. (2009). Maple Leaf Foods CEO Business Newsmaker of the Year. Digital Journal. Retrieved December 1, 2009 from http://www.digitaljournal.com/article/264355

Fearn-Banks, K. (2007). Crisis communications: A casebook approach. 3rd Edition. New Jersey: Lawrence Erlbaum Associates.

Fink, S. (1986). Crisis management: Planning for the inevitable. New York, N.Y.: American Management Association

Flynn, T. (2009). Authentic crisis leadership and reputation management: Maple Leaf Foods and 2008 Listeriosis Crisis. DeGroote School of Business, McMaster University.

Greenwood, J. (2009, February 3). Listeria costs Maple Leaf \$27M. National Post, p. FP7 .

Godbout, W. (2008, December 10). Media briefing with Maple Leaf president and CEO on new food safety protocols and plant tour. Maple Leaf Foods. Retrieved September 2, 2009 from http://investor.mapleleaf.ca/phoenix.zhtml?c=88490\&p=irolnewsArticle\&ID=1234735\&highlight=

Harris, M. (2009, January 22). Maple Leaf winning the battle to bring customers back. Canwest News Service.

Heath, R. (2001). Handbook of public relations. Thousand Oaks: Sage Publications.

Hermann, C. (1963). Some consequences of crisis which limit the viability of organisations. Administrative Science Quarterly, 8, 61-82.

Howell, G., \& Miller, R. (2006). How the relationship between the crisis life cycle and mass media content can better inform crisis communication. Prism, 4(1). Retrieved July 9, 2009, from http://praxis.massey.ac.nz/fileadmin/Praxis/Files/Journal_Files/2006_general/Howell_Miller.pdf

Jaques, T. (2007) Issue management and crisis management: An integrated, non-linear, relational construct. Public Relations Review, 33(2), pp147-157.

Johnson, J. \& Zawawi, C. (Eds.). (2002). Public relations: Theory and practice. Sydney: Allen \& Unwin

Kimmel, A. (2004). Rumours and rumour control: A manager's guide to understanding and combating rumours. New Jersey: Lawrence Erlbaum.

Kumar, S., \& Budin, E. (2006). Prevention and management of product recalls in the processed food industry: A case study based on an exporter's perspective, Technovation, 26(5-6), 739-750.

Lam, E. (2009, August 4). Maple Leaf shares rebound after earlier tumbling nearly 5\%. Financial Post. Retrieved September 1, 2009, from http://www.financialpost.com/story.html?id=1858023

Lagadec, P. (1993). Preventing chaos in a crisis. Maidenhead: McGraw-Hill.

Lerbinger, O. (1997). The crisis manager: Facing risk and responsibility. New Jersey: Lawrence Erlbaum Associates.

Levine, L. (1994). Listening with spirit and the art of team dialogue. Journal of Organisational Change Management, 7(1), 61-73.

Maple Leaf Foods. (2009a). Corporate profile. Retrieved March 1, 2009, from http://www.mapleleaf.com/

Maple Leaf Foods. (2009b). Food Safety Leadership blog. Retrieved April 1, 2009, from http://blog.mapleleaf.com/2009/03/the-journey-to-food-safety-leadership-45 
Maple Leaf Foods. (2009c). Maple Leaf Foods action plan. Retrieved March 1, 2009, from http://www.mapleleafaction.com/

Maple Leaf Foods. (2008a, September 5). Maple Leaf Foods Bartor Road Plant investigation. Media Backgrounder. Retrieved March 1, 2009, from http://www.mapleleaf.com/

Maple Leaf Foods. (2008b, August 20). Food safety fact sheet. Media Fact Sheet. Retrieved

March 1, 2009, from http://www.mapleleaf.com/

Maple Leaf Foods. (2008c, August 20). Food safety Q\&A Bartor Road. Media Q\&A. Retrieved March 1, 2009, from http://www.mapleleaf.com/

Maple Leaf Foods. (2008d, August 17). Health hazard alert sure slice brand roast beef and

corned beef may contain listeria monocytogenes. Media Release. Retrieved March 1, 2009, from http://www.mapleleaf.com/

Matera, F., \& Artigue, R. (2000). Public relations campaigns and techniques: Building bridges into the 21st century. Needham Heights, MA: Allyn \& Bacon.

Matheson, D. (2008, September 2). Maple Leaf Foods is living a 21st century corporate nightmare. The Daily Gleaner, p. C8.

McCain, M.. (2009, March 25). The journey to food safety leadership. Maple Leaf

Foods. Retrieved from http://blog.mapleleaf.com

Mitroff, I., \& Alpasian, M. (2003). Preparing for evil. Harvard Business Review, 81(4), 109-115.

Mitroff, I. I., Shrivastava, P., \& Udwadie, W. (1987). Effective crisis management. The Academy of Management Executive, 1(3), 283-292.

Michelson, G., \& Mouly, S. (2002). You didn't hear it from us but...: Towards an understanding of rumour and gossip in organisations. Australian Journal of Management, 27(Special Issue), 57-65.

Millar, D., \& Heath, R. (Eds.). (2004). Responding to crisis: A rhetorical approach to crisis communication. Mahwah: Lawrence Erlbaum Associates.

Moore, S. \& Seymour, M. (2000). Effective crisis management: Worldwide principles and practice. London: Cassell.

New South Wales Food Authority. (2006). Listeria monocytogenes. Fact Sheet. (July 16, 2006). Retrieved May 30, 2009, from http://www.foodauthority.nsw.gov.au/_Documents/consumer_pdf/listeria.pdf

Olanrian, B., \& Williams, D. (2001). Anticipatory model of crisis management: A vigilant response to technology crises. In R. Heath (Ed.), Handbook of public relations (pp. 487-500). Thousand Oaks.CA: Sage.

Owram, K. (2009, February 25). Maple Leaf Foods settles listeriosis suits. The Globe and Mail, p. A4.

Pan, Z., \& Kosicki, G. (1993). Framing analysis: An approach to discourse. Political Communication, 10(1), 55-75.

Patterson, B. (2004). A crisis media relations primer. Public Relations Tactics, 11(12), 13.

Pauchant, T., \& Mitroff, I. (1992). Transforming the crisis-prone organisation. San Francisco: JosseyBass.

Pearson, C., Misra, S., Clair, J., \& Mitroff, I. (1997). Managing the unthinkable, Organizational Dynamics, 26(2), 51-64

Penrose, J. (2000). The role of perception in crisis planning. Public Relations Review, 26(2), 155-171.

Pitts, G. (2008, December). The testing of Michael McCain. Report On Business Magazine, 46-51.

Public Health Agency of Canada. (2008). Link between listeriosis outbreak strain and Maple Leaf Foods products confirmed. Retrieved March 7, 2009, from http://www.phac-aspc.gc.ca/media/nrrp/2008/2008_13-eng.php

Russell, J. (2005). The Asian SARS crisis: Countering rumour as well as 'reality'. In C. Galloway and K. Kwansha-Aidoo (Eds.), Public relations issues and crisis communication (pp. 85-96). Sydney: Thomson Social Science Press.

Seymour, M., \& Moore, S. (2000). Effective crisis management: Worldwide principles and practice. London: Cassell.

Smith, L. (2008, August 23). Maple Leaf CEO Michael H. McCain responds to determination of link to plant. Maple Leaf Foods. Retrieved on September 1, 2009 from http://investor.mapleleaf.ca/phoenix.zhtml?c=88490\&p=irol-newsArticle\&ID=1189861\&highlight

Tattrie, J. (2009, February 20). Maple Leaf's handling of listeria crisis set 'the gold standard', experts say. Metro Halifax. Retrieved March 7, 2009, from http://www.metronews.ca/ 
Todd, J. (2008, September 29). A case study in effective crisis management. Law Times. Retrieved March 7, 2009, from http://www.lawtimesnews.com/200809294257/Headline-News/A-case-studyin-effective-crisis-management

Troester, R. (1991). The corporate spokesperson in external organisational communication: What we know and what we need to know. Management Communication Quarterly, 4(4), 528-540.

Ulmer, R., Seeger, M., Sellnow, T. (2007). Effective crisis communications: Moving from crisis to opportunity. Thousand Oaks, CA: Sage Publications.

The authors would like to thank Matt Chandler and Genevive Savundranayagam for their initial research on this paper.

* Dr Gwyneth Howell is senior lecturer in public relations at the University of Western Sydney, a position she has held for the past six years. She also has 18 years consulting experience in corporate and marketing communications and public relations. Her main research focus is strategic public relations, crisis and issues management, and social media marketing.

** Dr Rohan Miller is based in the Marketing Discipline in the Faculty of Economics and Business at the University of Sydney. His research focuses on marketing communications and public relations, consumer behaviour, negative consumption effects, and public policy. Dr Rohan also has extensive consulting experience in relation to government, gambling, banking and finance, and hospitality. 